\title{
:: Editorial
}

Revista Digital do LAV - Laboratório de Artes Visuais

Ano III - Número 05 - Setembro de 2010. ISSN 1983-7348

Estimados (as) Leitores (as)!

Temos o prazer de apresentar o quinto número da Revista Digital do LAV. Um periódico de caráter científico com periodicidade semestral, com ISSN, Conselho Editorial formado por pareceristas de diferentes IES do Brasil e do exterior, com duas edições publicadas regularmente no período previsto e conforme edital semestral no site http://www.ufsm.br/lav.

Recebemos para este número da revista vinte e seis artigos do Brasil e do exterior. Após análise do Conselho Editorial foram selecionados para publicação nove artigos. Sejam todos muito bem-vindos!

"Educación y cultura visual: aportaciones y relaciones necesarias" é o artigo proposto por Fernando Miranda. Fernando é professor titular e pesquisador da ENBA - Escuela Nacional de Bellas Artes - Universidad de La República - Uruguai. Neste texto Fernando discute a importância de estabelecer vínculos entre a perspectiva da cultura visual, o enfoque relacional e o desenvolvimento da experiência estética.

Em "Entender a educação como um ato de cultura: estratégias de formação artística" Anabela Moura nos apresenta sua pesquisa realizada em Portugal pelos professores do Departamento de Educação Artística da Escola Superior de Educação, do Instituto Politécnico de Viana do Castelo. Seu foco de interesse é a questão do patrimônio cultural.

Renata Favarin Santini propõe o texto "Corpos em deslocamento: sobre o percurso criativo da obra de Carlos Vergara". O artigo trata de questões que foram analisadas por Renata durante o Mestrado em artes visuais no PPGART/UFSM. Neste texto Renata discute três obras de Vergara.

"Criação na perspectiva da diferença" é a contribuição de Paola Zordan. Paola é professora do Programa de Pós Graduação em Educação da UFRGS e membro do grupo de pesquisa DIF: artistagens, fabulações e variações. O presente texto se configura como uma revisão de literatura quanto ao conceito de criação para melhor situar a perspectiva teórica junto a qual os trabalhos artísticos que consistem seu corpus serão posteriormente analisados.

"A formação inicial no curso de artes visuais da UFSM - envolvimentos de estagiários e orientadores" é o texto escrito pela professora da rede municipal de ensino no município de Chapecó/SC, Sandra Agostini. Na sua pesquisa de mestrado Sandra analisou a organização e o 
desenvolvimento de estágios curriculares em cursos de licenciatura da UFSM. Para esta ocasião nos traz o caso especifico das artes visuais

Nelcí Andreatta Kunzler atua no setor pedagógico da 36a coordenadoria regional de educação de ljuí/RS, na formação continuada dos professores de arte. Para este número da revista Nelcí nos apresenta "A arte visual no mundo contemporâneo" uma experiência de pesquisa desenvolvida no município de Jóia.

"StudioClio espaço de interações culturais: um olhar sobre a cultura, a arte e a gastronomia" é a proposta de Ana Méri Zavadil Machado, fruto da sua pesquisa de mestrado que analisa espaços culturais não institucionais.

Henrique Lima Assis, coordenador pedagógico do Ciranda da arte de Goiás nos convida para pensar as questões do ensinar e do aprender através do instigante texto "Narrativas de aprender, narrativas de ensinar: como venho aprendendo a ensinar artes visuais".

Em "Fontes imagéticas na poética de Andreas Gryphius" o pesquisador paulista Antônio Jackson de Souza Brandão explora a utilização de elementos imagéticos e suas fontes na Alemanha do século XVII e a partir daí busca demonstrar que a literatura barroca não deve ser compreendida como uma poética de experiências pessoais no sentido contemporâneo.

Desejo a todos e a todas uma excelente leitura!

\section{Marilda Oliveira de Oliveira}

Presidente da Comissão Editorial

Revista Digital do LAV 